\title{
An Epidemiologic and Microbiologic Profile of Children Aged 0-59 Months Admitted with Suspected Meningitis in VSMMC, Cebu, Philippines
}

\author{
Manoj Prasad Kushwaha ${ }^{1}$, Ramon V. Najarro ${ }^{2}$ \\ ${ }^{1}$ Pediatrician, M.D, Lumbini Zonal Hospital, Butwal, Rupandehi, Nepal \\ ${ }^{2}$ Ramon V. Najarro, M.D, FPPS, FPSCCMP; Pediatric Intensivist Chairman, Vicente Sotto Memorial Medical Center (VSMMC), Cebu, \\ Philippines
}

\begin{abstract}
Background \& Objective: Meningitis is an important cause of morbidity and mortality in low-resource settings\& remains a major cause of long term neurological sequelae worldwide. The purpose of present study was to identify the epidemiological and microbiological profile of suspected meningitis admitted in VSMMC, Cebu. This study provides information on meningitis causing pathogens and also justifies the importance of vaccines or other control measures as a strategy for improving population health. Materials \& Methods: Present study was undertaken from $1^{\text {st }}$ May 2013 to $30^{\text {th }}$ April 2014 included 180 suspected meningitis cases. CSF samples of clinically suspected meningitis cases in age group (0-59) months were subjected to macroscopic/ microscopic examination, Gram's stain and culture tests. The collected data were analyzed by using descriptive and inferential statistics. Results: Sixty-five samples out of 180 cases were positive on CSF culture. Bacillus was most common among age less than 1 month and Streptococcus pneumoniae was the most common pathogen among age group (2-12) months. Similarly, Pseudomonas stutzeri was the most common pathogen among age group (13-24) months followed by Mec-A Staphylococcus hominis among the age group (24-59) months. 51 out of 65 cases of isolates were gram positive pathogen. There was significant association between age of child and duration of symptoms at the time of admission (p-value=0.001). Conclusion: Regular prevalence, epidemiological and microbiological studies will help to detect the change in causative organism of meningitis and also help pediatricians in choosing an appropriate antimicrobial agent in VSMMC. The high prevalence of drug resistant pathogens is a cause for worry and should be dealt with by rational use of antibiotics.
\end{abstract}

Keywords: Meningitis, VSMMC, epidemiological, microbiological

\section{Introduction}

Meningitis is an important cause of morbidity and mortality in low-resource settings. Apart from epidemics, at least 1.2 million cases of meningitis are estimated to occur with estimated annual deaths of $170,000 .^{1,2}$ In the Philippines, bacterial meningitis is one of the top ten causes of death among children less than four years old. While bacterial meningitis is endemic in the Philippines, cases are mostly sporadic. $^{3}$

In developed countries, mortality is as high as $20-40 \%$ with long term neurologic damage in $30-50 \%$. In developing countries such as Thailand and the African nations, bacterial meningitis in neonates is associated with a $41-49 \%$ mortality rate and the incidence of neurologic sequelae among survivors is $38 \%$. ${ }^{4}$ Bacterial meningitis is caused by a number of organisms but beyond the neonatal period, over 90\% of infections are caused by Streptococcus pneumoniae (S. pneumoniae), Haemophilus influenza (H. influenza) and Neisseria meningitidis (N. meningitidis). ${ }^{5}$

Prompt and accurate diagnosis and adequate treatment of bacterial meningitis in children remains a major challenge, as reflected by the continued high morbidity and casefatality rates of the disease worldwide. ${ }^{6}$ Better understanding of pathophysiologic mechanisms likely would result in more effective therapies in the future. Use of conjugate vaccines against the most common pathogens has been crucial in preventing bacterial meningitis in children.
Various reasons cited in the literature for a low yield of bacteria on culture were delay in transport of specimens to the laboratory, non-availability of special media for specific, pathogens in the emergency setting, autolysis enzymes in $\mathrm{CSF}$, fastidious nature of pathogen and antibiotic treatment prior to lumbar puncture. ${ }^{7} \mathrm{~S}$. pneumoniae still remains a major cause of bacterial meningitis among all age groups and its susceptibility to penicillin, chloramphenicol and ceftriaxone still remains high. ${ }^{8}$

Over the last two decades however, the causative agents of meningitis has changed with the introduction of new highly effective vaccines. ${ }^{9}$ Haemophilusinfluenzae type b (Hib) used to be a common cause of bacterial meningitis worldwide before the Hib vaccines. ${ }^{10}$ However more recently, S. pneumoniae and $\mathrm{N}$. meningitidis have become the major organisms causing meningitis. However little information is available on the pathogens contributing to meningitis and their antimicrobial susceptibilities. Updated information is essential to adjust the recommendations for empirical treatment or prevention of meningitis which could have immense implications for local and global health. ${ }^{8}$

This study is therefore important as it provides information on meningitis causing pathogens circulating throughout the years and also justifies the importance of vaccines or other control measures as a strategy for improving population health. 


\section{International Journal of Science and Research (IJSR) \\ ISSN (Online): 2319-7064}

Index Copernicus Value (2016): 79.57 | Impact Factor (2015): 6.391

\section{Objectives}

- To determine the epidemiologic profile of the children in terms of age, sex, place and mode of delivery of the child.

- To identify the different pathogens responsible for meningitis in patient admitted in VSMMC.

- To find out the association between selected sociodemographic variables \& duration of symptoms at the time of admission in cases of suspected meningitis.

\section{Materials and Methods}

- Design: A cross-sectional descriptive prospective study design.

- Setting: Pediatric ward of VSMMC, Cebu, Philippines. Sample Size: The total number of admission according record of VSMMC was 572 with suspected meningitis from 1st May 2013 to 30th April 2014, but only 180 gave consent to participate in the study so, 180 cases of suspected meningitis was enrolled in the study. The total sample size was 180 .

- Sampling Technique: Total Population Enumerative Sampling Technique.

- Research Instrument: A self-prepared, pretested semistructured questionnaire was used.

- Data Collection Procedure: Data was collection after obtaining permission from the Institutional Review Committee and all the concerned authority of VSMMC, Cebu. Pretesting and was done and necessary modifications was done in the tool before starting data collection procedure. Informed written consent was obtained from each respondent. Data was retrieved from laboratory record books as well.

- Data Analysis Procedure: Collected data were analyzed using descriptive statistics (Median, Inter Quartile Range, Percentage and Frequency) and inferential statistics (Chisquare test) using SPSS version 16. The p-value was calculated at $95 \%$ Confidence Interval and 5\% permissible error.

\section{Results \& Findings}

Regarding the findings related to socio-demographic information, the study showed that more than half (55.6\%) of the children were male and only forty four of children were female $(44.4 \%)$. More than half $(51.7 \%)$ of the children were born at home whereas only about $48 \%$ children were born at Health Institution. Majority $(85.0 \%)$ of the children were delivered through Spontaneous Vaginal Delivery whereas only $15 \%$ were delivered through Caesarean Section.

Table 1: Socio-demographic Profile of the Child (Age at Admission) $(\mathbf{n}=\mathbf{1 8 0})$

\begin{tabular}{|c|c|c|}
\hline Age (in months) & Frequency & Percentage (\%) \\
\hline$\leq 1$ & 27 & 15.00 \\
\hline $2-12$ & 63 & 35.00 \\
\hline $13-24$ & 61 & 33.90 \\
\hline $25-36$ & 11 & 6.11 \\
\hline $37-48$ & 14 & 7.80 \\
\hline $49-60$ & 4 & 2.20 \\
\hline \multicolumn{2}{|c|}{ Median age at admission (IQR) } & $\mathbf{1 2 ( 5 - 2 0 )}$ months \\
\hline
\end{tabular}

Key: IQR: Inter Quartile Range
Table 1 shows that the age at admission of more than one third $(35.00 \%)$ of the children belongs to age group (2-12) months and the median age at admission was 12 months. The age at admission of age group $(\geq 49)$ months was found to be very less $(2.22 \%)$

Table 2: Clinical Profile of Child with Suspected Meningitis $(\mathbf{n}=\mathbf{1 8 0})$

\begin{tabular}{|c|c|c|c|}
\hline Variables & Categories & Frequency & $\begin{array}{c}\text { Percentage } \\
(\%)\end{array}$ \\
\hline \multicolumn{4}{|c|}{ Characteristics at diagnosis } \\
\hline \multirow{7}{*}{$\begin{array}{c}\text { Chief complaints at } \\
\text { the time of admission }\end{array}$} & Fever & 180 & 100 \\
\hline & Seizures & 172 & 95.56 \\
\hline & $\begin{array}{l}\text { Poor sucking/ } \\
\text { feeding }\end{array}$ & 31 & 17.22 \\
\hline & Vomiting & 31 & 17.22 \\
\hline & $\begin{array}{l}\text { Altered sensorium } \\
\text { and lethargy }\end{array}$ & 24 & 13.33 \\
\hline & Bulging fontanel & 7 & 3.89 \\
\hline & Nuchal rigidity & 6 & 3.33 \\
\hline \multirow{2}{*}{$\begin{array}{c}\text { Seizures at the time of } \\
\text { admission }\end{array}$} & Yes & 32 & 17.80 \\
\hline & No & 148 & 82.20 \\
\hline \multirow{2}{*}{$\begin{array}{l}\text { Seizures after } \\
\text { admission }\end{array}$} & Yes & 81 & 45.00 \\
\hline & No & 99 & 55.00 \\
\hline \multirow{2}{*}{$\begin{array}{l}\text { Received antibiotics } \\
\text { prior to diagnosis }\end{array}$} & Yes & 64 & 35.60 \\
\hline & No & 116 & 64.40 \\
\hline \multirow{2}{*}{$\begin{array}{c}\text { Duration of symptoms } \\
\text { at the time of } \\
\text { admission }\end{array}$} & $<24$ hours & 108 & 60.00 \\
\hline & $\geq 24$ hours & 72 & 40.00 \\
\hline
\end{tabular}

Table 2 shows that all the cases $(100 \%)$ were diagnosed as the case of suspected meningitis. Every child had fever $(100 \%)$ at the time of admission. More than two third $(95.56 \%)$ of the child had seizures at the time of admission. About $45 \%$ of the children had seizures after admission. Others chief complaints such as bulging fontanel and nuchal rigidity were least common among children in VSMMC. More than thirty percent of the children had received antibiotics prior to diagnosis. Majority (60\%) of the children had been brought to the hospital within 24 hours of duration of symptoms at the time of admission to hospital.

Table 3: Lab Investigations $(\mathbf{n}=\mathbf{1 8 0})$

\begin{tabular}{|c|c|c|c|}
\hline Variables & Categories & Frequency & $\begin{array}{c}\text { Percentage } \\
(\%)\end{array}$ \\
\hline \multirow{2}{*}{$\begin{array}{l}\text { Lumbar puncture } \\
\text { (LP) done }\end{array}$} & Yes & 180 & 100 \\
\hline & No & 0 & 0 \\
\hline \multirow{2}{*}{$\begin{array}{c}\text { Meningitis causing } \\
\text { Bacterial pathogen } \\
\text { in CSF Analysis }\end{array}$} & $\begin{array}{l}\text { Bacterial pathogen growth } \\
\text { seen in culture i.e present }\end{array}$ & 65 & 36.11 \\
\hline & $\begin{array}{l}\text { Bacterial pathogen growth } \\
\text { absent in culture }\end{array}$ & 115 & 63.89 \\
\hline \multirow{13}{*}{ CSF Analysis } & Gross appearance: Clear & 166 & 92.22 \\
\hline & Cloudy & 12 & 6.67 \\
\hline & Bloody & 1 & 0.55 \\
\hline & Yellow & 1 & 0.55 \\
\hline & \multicolumn{3}{|c|}{ CSF glucose level } \\
\hline & $\begin{array}{c}\text { Median glucose level in CSF } \\
\text { (IQR) in } \mathrm{mg} / \mathrm{dl}\end{array}$ & \multicolumn{2}{|c|}{$60(38-75) \mathrm{mg} / \mathrm{dl}$} \\
\hline & \multicolumn{3}{|c|}{ CSF protein level } \\
\hline & $\begin{array}{c}\text { Median protein level in CSF } \\
\text { (IQR) in } \mathrm{mg} / \mathrm{dl}\end{array}$ & \multicolumn{2}{|c|}{$38(23-72) \mathrm{mg} / \mathrm{dl}$} \\
\hline & \multicolumn{3}{|c|}{ Leucocytes: } \\
\hline & $0 \mathrm{ul}$ & 123 & 68.33 \\
\hline & $1-5 \mathrm{ul}$ & 30 & 16.67 \\
\hline & $6-10$ & 5 & 2.78 \\
\hline & $>10 \mathrm{ul}$ & 22 & 12.22 \\
\hline
\end{tabular}




\section{International Journal of Science and Research (IJSR) \\ ISSN (Online): 2319-7064}

Index Copernicus Value (2016): 79.57 | Impact Factor (2015): 6.391

Table 3 shows that all the children diagnoses as suspected meningitis had all gone under lumbar puncture. Gross appearance of CSF was clear in 166 cases. The median Glucose concentration was $60 \mathrm{mg} / \mathrm{dl}$ and protein concentration was $38 \mathrm{mg} / \mathrm{dl}$. The cell type leucocytes were found in 57 cases only and was within range (1-5) ul in 30 cases only.

The study illustrated that $65(36.11 \%)$ out of 180 samples revealed microbial growth in CSF culture. The most common bacterial pathogen of suspected meningitis was found to be Streptococcus pneumoniae $(7.80 \%)$ and Mec-A Staphylococcus hominis $(6.70 \%)$ followed by Pseudomonas stutzeri (5.0\%), Bacillus sps (2.2\%), Streptococcus mitis (1.7\%), Staphylococcus epidermidis (1.7\%), Streptococcus viridans (1.7\%), Pseudomonas fluorescens $(0.6 \%)$ and Micrococcus $(0.6 \%)$. Regarding the CSF isolates, 51 out of 65 isolates were Gram Positive and among them Streptococcus pneumoniae $(21.54 \%)$ was the common CSF isolates. Fourteen out of sixty-five CSF isolates were Gram Negative and Pseudomonas stutzeri (13.85\%) was the most common pathogen.

Similarly, Bacillus (1.67\%) was the most common bacterial pathogen in neonates of less than 1 month whereas in the age group (2-12) months, Streptococcus pneumoniae $(4.44 \%)$ was the common bacterial pathogen as per CSF analysis results. Pseudomonas stutzeri $(2.78 \%)$ was common among age group (13-24) months. Accordingly, Mec-A Staphylococcus hominis was the common pathogen in age group above 24 months. In total, 13 pathogens was identified in age less than 1 months; 23 pathogens in (2-12) months; 20 pathogens in (13-24) months; 4 pathogens in (25-36) months; 5 pathogens in (37-48) months and 1 pathogen in (49-60) months.

Table 4: Distribution of micro-organisms according to Socio-demographic Profile $(n=65)$

\begin{tabular}{|c|c|c|c|c|}
\hline & \multicolumn{2}{|c|}{ Place of delivery } & \multicolumn{2}{c|}{ Mode of delivery } \\
\cline { 2 - 5 } & Home (n, \%) & $\begin{array}{c}\text { Health } \\
\text { Institution } \\
(\mathbf{n , \%})\end{array}$ & $\begin{array}{c}\text { Spontaneous } \\
\text { vaginal delivery } \\
(\mathbf{n}, \%)\end{array}$ & $\begin{array}{c}\text { Caesarean } \\
\text { section } \\
(\mathbf{n}, \%)\end{array}$ \\
\hline $\begin{array}{c}\text { Gram } \\
\text { positive } \\
(\mathrm{n}=51)\end{array}$ & $32(49.23 \%)$ & $\begin{array}{c}19 \\
(29.23 \%)\end{array}$ & $\begin{array}{c}46 \\
(70.78 \%)\end{array}$ & $\begin{array}{c}5 \\
(7.69 \%)\end{array}$ \\
\hline $\begin{array}{c}\text { Gram } \\
\text { negative } \\
\text { (n=14) }\end{array}$ & $5(7.69 \%)$ & 9 & 11 & 3 \\
\hline Total: & $37(56.92 \%)$ & $\begin{array}{c}28 \\
(43.08 \%)\end{array}$ & $\begin{array}{c}57 \\
(87.69 \%)\end{array}$ & $\begin{array}{c}8 \\
(12.31 \%)\end{array}$ \\
\hline
\end{tabular}

Table 4 depicts that Gram positive micro-organisms were common in Home Delivery $(49.23 \%)$ than Health Institution delivery $(29.23 \%)$ whereas Gram negative organism were common in Health institution delivery (13.85\%). Similarly, Gram negative organisms were common in Spontaneous Vaginal Delivery (16.92\%) than Caesarean Section (4.62\%). Gram positive was common in Spontaneous Vaginal Delivery $(70.78 \%)$. There was no growth of pathogen seen in 56 cases of home delivery and 59 cases of Health Institution delivery whereas no growth of pathogen seen in 96 cases of Spontaneous Vaginal Delivery and 19 cases of Caesarean Section.
Table 5: Association between duration of symptoms in suspected cases of meningitis and selected socio-

\begin{tabular}{|c|c|c|c|c|}
\hline \multicolumn{5}{|c|}{ demographic variables $(n=180)$} \\
\hline \multirow[t]{2}{*}{ Variables } & \multirow[t]{2}{*}{ Categories } & \begin{tabular}{|r} 
Du \\
syı \\
suspec \\
at \\
a \\
\end{tabular} & $\begin{array}{l}\text { of } \\
\text { s in } \\
\text { ningitis } \\
\text { e of } \\
\text { on } \\
\end{array}$ & \multirow[t]{2}{*}{$\begin{array}{c}\text { p- } \\
\text { value }\end{array}$} \\
\hline & & \multicolumn{2}{|c|}{$\mid<24$ hours $\geq 24$ hours } & \\
\hline \multirow{2}{*}{$\begin{array}{c}\text { Age at } \\
\text { admission } \\
\text { (in months)** }\end{array}$} & $\leq 1$ & 24 & 3 & \multirow[b]{2}{*}{0.001} \\
\hline & $2-60$ & 84 & 69 & \\
\hline \multirow{2}{*}{$\begin{array}{l}\text { Sex of the } \\
\text { Child* }\end{array}$} & Male & 59 & 41 & \multirow{2}{*}{0.440} \\
\hline & Female & 49 & 31 & \\
\hline \multirow{2}{*}{$\begin{array}{c}\text { Place of } \\
\text { Delivery* }\end{array}$} & Home & 56 & 37 & \multirow{2}{*}{0.536} \\
\hline & Health Institution & 52 & 35 & \\
\hline \multirow{2}{*}{$\begin{array}{l}\text { Mode of } \\
\text { Delivery* }\end{array}$} & $\begin{array}{c}\text { Spontaneous } \\
\text { Vaginal Delivery }\end{array}$ & 93 & 60 & \multirow{2}{*}{0.379} \\
\hline & Caesarean Section & 15 & 12 & \\
\hline
\end{tabular}

Key:

* Chi-square Test

**Fischer's Exact Test

Table 5 shows that there was statistically significant association between age at admission and duration of symptoms in suspected meningitis at the time of admission ( $p$-value $=0.001$ ). This concludes that children more than 1 months of age were brought within 24 hours to the health institution for treatment as compared to neonates less than 1 month.

\section{Discussion}

The age at admission of the majority (35.00\%) of the children belongs to age group (2-12) months and the median age at admission was 12 months. The age at admission of age group $(\geq 48)$ months was very less $(2.22 \%)$ only. A study done in Bohol, Philippines concluded that out of 205 samples, (0-1) month was $22.44 \%$ and (1-12) months were $14.15 \%$ only ${ }^{11}$. The present study was done in pediatric wards of VSMMC only whereas the study done in Bohol, was conducted in Neonatal ICU $(22.43 \%$ of meningitis cases), Pediatric ward (37.56\%) and Neuro-surgical ward $(15.12 \%){ }^{11}$

More than half (56\%) of the children were male and only 44 out of 180 children were female. Similarly, more than half of the children were born at Home whereas only about $48 \%$ children were born at Health Institution. A study done in Bohol, Philippines found that among 205 samples, 60\% was male which was similar to the findings of this study. ${ }^{11}$

A study done by Chugh Y among ${ }^{12}, 638$ cases in septic meningitis found that among neonates, abnormal body temperature in 25 cases, convulsion in 22 cases and refusal to feed in 19 cases. But among infants, convulsions in 19 cases followed by fever in 18 cases and shrill cry in 17 cases. Anterior fontanel bulging ( 8 cases) was the least found clinical manifestation among infants. Among older adults, convulsion in 42 cases followed by fever in 40 cases and altered sensorium in 39 cases. Neck rigidity (18 cases) and Photophobia (11 cases) were the least findings in his study. Seizures are more common in children with meningitis caused by S. pneumoniae which was consistent with the findings of the present study. 


\section{International Journal of Science and Research (IJSR) \\ ISSN (Online): 2319-7064}

Index Copernicus Value (2016): 79.57 | Impact Factor (2015): 6.391

A study done by Agrawal S in London found H. influenza, Streptococcus pneumoniae and N. meningitides as the major cause of Acute Bacterial Meningitis. ${ }^{13}$ Another study done in Yemen found that Streptococcus pneumoniae (30.1\%), H. influenza (15\%), N. meningitides $(52.9 \%)$, S. aureus $(1.3 \%)$ and E. coli $(0.7 \%)$ were the common pathogens ${ }^{14}$ which was consistent with the findings of the present study.

A study done in India in 2011-2013 found that Gram positive organism was $(63 \%)$ and among Gram positive isolates, Streptococcus pneumoniae and Klebsiella pneumoniae were the common pathogens ${ }^{15}$ whereas Gram positive micro-organisms were common in Home Delivery (49.23\%) than Health Institution delivery (29.23\%) whereas Gram negative organism were common in Health institution delivery $(13.85 \%)$ in the present study.

This study finding is unlike to the study done by Chugh $\mathrm{Y}$ among 638 cases in the age group (1-12 years). In his study, incidence of Gram positive CSF isolates were high in Health Institutional delivery (39 cases out of 58 cases) and Spontaneous Vaginal Delivery (50 cases out of 79 cases). His study also stated that maximum incidence (51 cases) was in summer-rainy season which was not done in our study. Whereas culture positive were found in children aged $(1-12)$ years. ${ }^{12}$

Regarding association between duration of symptoms at the time of admission and selected variables, the study showed that there was statistically significant association between age at admission and duration of symptoms in suspected meningitis at the time of admission ( $\mathrm{p}$-value $=0.001$ ). This highlights that children of more than 1 month of age with suspected meningitis, were brought earlier i.e. within 24 hours to the hospital for treatment. The median age at admission for duration of symptoms at the time of admission within 24 hours was found to be 3 months and after 24 hours was calculated to be 15 months.

An observational analytical study done by Khichi G.Q from 2000 to 2002 among 300 admitted cases of pyogenic meningitis of Pediatric medicine unit in B.V hospital of Bahawalpur found that the outcome at the time of admission was statistically significant in prolonged duration of illness (chronicity prior to admission and increased cerebrospinal fluid (CSF) neutrophils after 1st lumbar puncture. Among the etiological microorganisms isolated from culture of CSF, only Streptococcus pneumoniae had statistically significant association; ${ }^{16}$ which is unlike to this study where association of pathogen was not done.

The epidemiology of Cebu, Philippines is a tropical country characterized by relatively high temperature, oppressive humidity and plenty of rainfall, ${ }^{17}$ where hardly bacteria like Staphylococcus sps and gram negative bacilli flourish, and the relatively more fragile bacteria like Acenobactersps, N. meningitidis, S. pneumoniae, Pseudomonas sps and Streptococcus infant coli in comparison do not have a survival advantage. Secondly, the predominance of patients from low socio-economic status with poor hygiene, poor nutrition and low birth weight leading to protein energy malnutrition gives an opportunity for the uncommon pathogens like Streptococcus species to cause meningitis.
Finally, unfortunately most of the patients turn to the tertiary care centre after taking treatment from local practitioners which may lead not only to culture negative results but also to lower isolation of Mec-A Streptococcus hominis, N. meningitidis, S. pneumoniae, Streptococcus cohnii, Streptococcus hemolyticus, Streptococcus viridans, P. stuszeri and Streptococcus infant coli which have not developed significant resistance to the usual antimicrobials. These results highlight the very different epidemiological and microbiological profile in Cebu, Philippines.

\section{Conclusion}

Streptococcus pneumoniae, Mec-A Staphylococcus hominis, Streptococcus saprophyticus, Streptococcus viridans, Streptococcus mitis, Staphylococcus cohnii, Acenobacterlwoffi, Bacillus species, Diptheroids, Micrococcus species, Staphyococcusepidermidis, Neisseria meningitides and Pseudomonas stutzeri were the major pathogens responsible for bacterial meningitis in pediatric age group. There is a need for periodic surveillance of pathogens in meningitis. These results signify the varying levels of drug resistance amongst the gram positive and the gram negative microbes, and the need to control the spread of these resistant strains before they reach the alarming levels in this region. It is particularly useful for the clinicians to possess the susceptibility data on Gram positive and Gram negative bacteria rather than for particular organisms only. This study also indicates the urgent need for more of such studies in the patients of meningitis via etiology and drug resistance along with the need for the in-house review of drug policy within hospitals at least once in every five years.

\section{Limitations of the Study}

The study has limitation of being representative of only the selected area and, cannot be generalized for the entire population of Philippines. This was a prospective study; the sample size was small and was conducted in only one center. Future studies should be multi-centric. Status of Hib vaccine could not be assessed due to time bound, and small sample size and so, this is recommended for further study

\section{Acknowledgement}

The authors wish to acknowledge all the staffs of VSMMC, Cebu, Philippines for their valuable support and guidance.

\section{References}

[1] World Health Organization: Meningococcal meningitis. 2012.[ Available from: http://www.who.int/mediacentre/factsheets/fs141/en/ind ex.html].

[2] Grimwood K, Anderson P, Anderson V, Tan L, Nolan T. Twelve year outcomes following bacterial meningitis: further evidence for persisting effects. Arch Dis Child. 2000. 83(2).

[3] Meningitis in the Philippines. [Retrived from http://health.wikipilipinas.org/index.php?title=Meningiti s on 1st Jan 2014].

[4] Ana Marie R. M, Salvacion R.G. Clinical Profile of Meningitis among Filipino Neonates: A twelve year

\section{Volume 6 Issue 12, December 2017}




\section{International Journal of Science and Research (IJSR) \\ ISSN (Online): 2319-7064}

Index Copernicus Value (2016): 79.57 | Impact Factor (2015): 6.391

Collaborative Review. [Retrived from www.pidsphil.org/pdf/Journal_04230733/jo14_ja04.pdf on 16th October 2014].

[5] Renner LA, Newman MJ, Ahadzie L, Antwi-Agyei KO, Eshetu M. Introduction of Haemophilusinfluenzae type B conjugate vaccine into routine immunization in Ghana and its impact on bacterial meningitis in children younger than five years. Pediatr Infect Dis J. 2007. 26(4).

[6] Cha'vez-Bueno S, McCracken GH. Bacterial Meningitis in Children. PediatrClin N Am. 2005. 52.

[7] Madhumita P, Gupta N. Clinical and bacteriological spectrum of community-acquired acute bacterial meningitis in adults at a tertiary care hospital in northern India. International J Nutrition, Pharmacology, Neurological Diseases. 2011;1(2):194-200.

[8] Owusu M, Nguah SB, Boaitey YA, Boateng EB, Abubakr AR, Lartey RA, Sarkodie YA. Aetiological agents of cerebrospinal meningitis: a retrospective study from a teaching hospital in Ghana. Ann ClinMicrobiolAntimicrob. 2012 Oct;11:28.

[9] Martin M, Casellas JM, Madhi SA, Urquhart TJ, Delport SD, Ferrero F, Chamany S, Dayan GH, Rose CE, Levine OS, Klugman KP, Feikin DR. Impact of haemophilusinfluenzae type $\mathrm{b}$ conjugate vaccine in South Africa and Argentina. Pediatr Infect Dis J. 2004. 23(9).

[10] Matthijs C. Brouwer, Allan R. Tunkel, Diederik van de Beek. Epidemiology, Diagnosis, and Antimicrobial Treatment of Acute Bacterial Meningitis. ClinMicrobiol Rev. 2010. 23(3).

[11] ModiGaurav B, Patel Komal D, SoniSumeeta T, Patel Kanu J, MangukiyaJayasukh D, Jain Pooja S. Bacteriological profile of pyogenic Meningitis in tertiary care hospital, Ahmedabad. National Journal of Medical Research. 2012. 2(3).

[12] Chugh Y, Kapoor AK, Kastury N, Srivastava AK, Bhargava A, Sharma A. Study of antimicrobial sensitivity pattern of Gram-positive CSF isolates among children suffering from septic meningitis in a tertiary care hospital. JIACM. 2011. 12(4).

[13] Agrawal S, Nadel S. Acute Bacterial Meningitis in infants and children: Epidemiology and management. Paediatr Drugs. 2011. 13(6).

[14] AI Khorasani, Banajeh S. Bacterial profile and clinical outcome of childhood meningitis in rural Yemen: A 2 year hospital based study. J Infect. 2006. 53(4).

[15] Sudharshan Raj. C, Pradeep Reddy. M, Neelima. A. Pattern and antibiogram of bacterial meningitis in children at a tertiary care hospital. Journal of Scientific and Innovative Research 2013; 2 (6).

[16] Khichi GQ, Channar M.S, Mannan MA. Mortality variables in Pyogenic meningitis in pediatric age group. J Cell Physicians Surg Park. 2003; 13 (10).

[17] Climate of the Philippines. Retrived from http://en.wikipedia.org/wiki/Climate_of_the_Philippine s on 22nd April 2014.

\section{Author Profile}

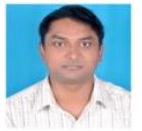

Dr. Manoj Prasad Kushwaha, M.D Paediatrics, Lumbini Zonal Hospital, Butwal, Rupandehi, Nepal 